\title{
Profiling of Universitas Ciputra Surabaya Student Satisfaction with
}

\author{
Property Management Services \\ Melissa Christina \\ Universitas Ciputra Surabaya \\ melissa.christina83@gmail.com \\ https://doi.org/10.37715/rmbe.v1i2.2426
}

\begin{abstract}
Increasing competition in service quality, universities must be responsive in providing services to students, because student satisfaction is the top priority for highest education. This study aims to see how much the average level of respondents to the quality of Universitas Ciputra Surabaya Property Management services. Measurements were made using the servqual instrument, namely Tangibles, Reliability, Responsiveness, Assurance, and Empathy. The analysis used in this research is descriptive statistics. The population in this study were active students at Universitas Ciputra Surabaya with a sample size of 186 people. Based on the results of the analysis that has been carried out, it is known that the level of satisfaction of the respondents with an overall average value is 3.97. And of the five factors used, only the Assurance factor gets an average score above 4, while the other four factors get an average score below 4 in the order Tangibles, Reliability, Responsiveness and Empathy as the factors with the lowest level of satisfaction.
\end{abstract}

Keywords — Level Of Satisfaction, Service Quality, College, Facilities.

\section{Introduction}

In its development, in addition to being a center for gaining knowledge, universities also compete fiercely in terms of service quality, facilities and infrastructure, prices and promotions. Higher competition for service quality makes universities have to be responsive in providing services to students, because student satisfaction is a top priority for universities. According to Low's opinion in Gold (2001) students are the main customers of higher education, higher education services should be student-oriented. Aliffudin (2012) reminded that education services are indeed student rights that must be fulfilled by universities as service providers. The success of a university is largely determined by the quality of services provided, where service quality can be identified through customer satisfaction, in this case students (Srinadi \& Nilakusmawati, 2008). According to Purwandani (2016) to win the competition in the world of education, universities must be able to provide satisfaction to their customers (students), namely by providing quality products, in the form of educational services.

The improvement of the quality of higher education is also carried out by Universitas Ciputra Surabaya. Universitas Ciputra Surabaya was founded in 2005 by Dr (HC). Ir. Ciputra, who has aspirations to grow the number of Entrepreneurs in Indonesia, so that they can create jobs in Indonesia. Universitas Ciputra Surabaya has 11 undergraduate programs (S1) and 1 postgraduate program (S2) with a commitment that each student can become an entrepreneur according to their respective expertise. To support this, Universitas Ciputra Surabaya provides facilities which include classrooms, library rooms, laboratory rooms, studio rooms, auditorium rooms, and mini theater rooms. Other infrastructure supporting academic activities such as discussion rooms, pre function, prayer rooms, counseling rooms, health rooms, canteens and sports fields. The management system for facilities and infrastructure at Universitas Ciputra Surabaya is regulated in the Rector's Decree No. 007/a/Kep.R/UC/IV/2011 concerning the Determination of the Quality Manual of Universitas Ciputra Surabaya. The facilities and infrastructure program is carried out centrally under the management of the Property Management (PM) department. Centralized procurement and management of facilities and infrastructure has an impact on the efficiency of the budget and also on the effectiveness of the speed and control of the procurement of facilities and infrastructure.

Servqual is a tool to measure the reality and expectations of service quality from the customer's point of view. There are five dimensions of servqual that are used to measure service quality, namely tangibles (physical buildings, campus facilities, equipment), reliability (ability to perform services on time and appropriately), 
responsiveness (desire to provide and help students quickly), assurance (knowledge and the ability of PM staff to generate student trust) and empathy (concern for students). The five dimensions of servqual will be an instrument for measuring student satisfaction with PM services.

\section{Literature Review}

\subsection{Previous Research}

The first research is "The Importance of University Facilities for Student Satisfaction at a Norwegian University' which was researched by Hanssen and Solvoll (2015). This research aims to analyze the effect of existing facilities in universities on overall student satisfaction. The results of the study found that university facilities that affect student satisfaction consist of four areas, namely the first social areas such as hallways and areas to relax for students and interact with educators and other students.

The second study was researched by Kärnä \& Julin (2015) entitled "A framework for measuring student and staff satisfaction with university campus facilities". The purpose of this study was to evaluate the satisfaction level felt by students and staff, as well as to analyze the factors related to facilities that have the greatest impact on student and staff satisfaction from the two campuses, namely Otaniemi University and Arabia Campus in Finland. Things that affect student satisfaction at Otaniemi University are effective learning and a comfortable environment, as well as the existence of public spaces for students and staff. Student satisfaction at Arabia University is influenced by the ease of campus accessibility. Satisfaction of Otaniemi University staff is influenced by comprehensive campus experience, while satisfaction of Arabian staff is influenced by laboratory and teaching facilities that create positive values.

The third research conducted by Srinadi and Nitakusmawati (2008), entitled Determinants of student satisfaction with faculty services as an educational institution, aims to determine the factors that determine student satisfaction and determine the dominant factor and determine the indicators that make up the dominant factor. The results of this study indicate that there are five determinants of satisfaction, namely tangibles, reliability, responsiveness, assurance, and empathy. Based on the results of this study, the reliability factor must first be improved, because it has a dominant influence in determining student satisfaction with the services of FMIPA Unud as an educational institution.

The fourth study entitled "Flexible spaces... what students expect from university facilities" was studied by McLaughlin and Faulkner (2012). The aim of this study was to determine the type of learning facilities desired by a small number of RMIT first year students in Melbourne. The results of the study indicate that educational facilities and their design have a considerable impact on the student learning system. This is because students now spend less time on campus, and spend more time interacting with friends through the help of technology. Therefore students want a flexible and adaptable study space where students can study individually or collaborate with the support of advanced technology.

The fifth study was conducted by Weerasinghe and Fernando (2018), entitled University facilities and student satisfaction in Sri Lanka. The purpose of this study was to determine the impact of university facilities on student satisfaction in Sri Lanka. The results of this study found that lecture halls, libraries, accommodation, entertainment rooms are strong factors in influencing student satisfaction. While computer facilities have no significant effect on student satisfaction. Weeringhe and Fernando recommended to the university to improve the study room facilities by improving the quality of the projector, sound system quality, ceiling, and air circulation in the room.

\subsection{Dimensions of Service Quality}

Service quality is the level of excellence of a service that is expected by the customer and controlled by the service actor (Fandy Tjiptono, 2005). According to Parasuraman et al. (1988) there are five dimensions of work quality called Servqual (Service Quality), consisting of:

1. Tangible (tangible), namely the ability of a company to show its existence to external parties. This includes physical facilities (buildings, warehouses, etc.), equipment and tools used and the appearance of employees. 
2. Reliability, namely the company's ability to provide services as promised accurately and reliably. Performance must be in accordance with customer expectations which means timeliness, service and attitude.

3. Responsiveness (responsiveness), which is a policy to help and provide fast and appropriate service to customers, with clear information delivery.

4. Assurance (guarantee), namely knowledge, courtesy, the ability of company employees to foster customer trust in the company.

5. Empathy, namely giving sincere attention to customers with an effort to understand customer desires.

\subsection{Customer satisfaction}

Customer satisfaction according to Tjiptono and Chandra (2011) customer satisfaction is not an absolute concept, but relatively depending on what customers expect. According to Irawan (2003) there are five factors that determine customer satisfaction, namely:

1. Product quality, consumers or customers will feel satisfied if the evaluation results show that the products they use are of high quality.

2. Quality of service, service quality is currently not only focused on the pure service industry, because all companies provide services for customers, customers will feel satisfied if they get good service or as expected.

3. Emotional factors, consumers will feel proud and gain confidence that other people will be amazed at him when using products with certain brands tend to have a higher level of satisfaction. Satisfaction is not due to the quality of the product but the emotional value that makes customers satisfied with a particular product brand.

4. Price, products that have the same quality but set a relatively cheap price will provide a higher value to its customers

5. Cost and ease of obtaining a product or service. Customers do not need to incur additional costs or do not waste time to get a product or service will tend to be satisfied with certain products or services.

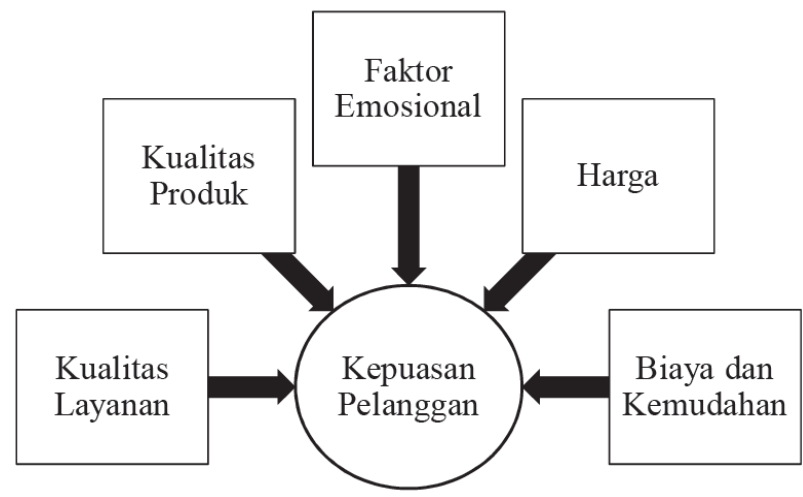

Figure 2.1. Factors Affecting Customer Satisfaction

\subsection{College Service}

The definition of higher education according to the Indonesian government regulation No. 12 of 2012 is an educational unit that organizes higher education. According to Indrajit and Djakopranoto (as cited in Wijatno, 2009), explain the five dimensions inherent in higher education, namely:

\section{Ethical Dimension}

Universities are referred to as centers of creativity and centers for the dissemination of knowledge

\section{Scientific dimension}

The aim is to develop and disseminate science, technology, and culture through teaching and learning processes and community service. 


\section{Education dimension}

In higher education, students are prepared from an early age to become educated human beings which are not only limited to the scope of formal education, but also non-formal, such as gaining additional knowledge from the surrounding community by serving others.

\section{Social dimension}

Colleges prepare students to take on responsibilities in society. From its graduates, the community expects continuous renewal and improvement in the way of life in society and the state.

\section{Corporate dimension}

The main product of higher education is knowledge provided to the public in the form of higher education services, so that the main business of higher education is science. The main service users of universities are students. In private universities, students are the main source of funding, so that a small number of students will result in universities being unable to finance themselves, resulting in a deficit. The main goal of higher education is to advance science and community service.

\subsection{Student Satisfaction}

The definition of students according to the RI government regulation No. 12 of 2012 is students at the higher education level. According to Sopiatin (2010) student satisfaction is a student's positive attitude towards the services of higher education institutions because of the compatibility between the expectations of the service compared to the reality they receive. Hasan et al. (2009) states that satisfaction in educational institutions includes the perceptions and experiences of teaching participants during their education period.

\section{Research Methods}

\subsection{Research Approach}

This research is a descriptive qualitative research. According to Sugiyono $(2015$, p. 1), qualitative research methods are research methods used to examine the condition of natural objects, (as opposed to experiments) where the researcher is the key instrument. The process and analysis are made based on a subjective perspective, in this study the theoretical basis is used as a guide so that the research focus is in accordance with the facts on the ground. In this study the population is Universitas Ciputra Surabaya students who are active in the organization is a number of 673 students. To calculate the number of samples needed, we use the Krejcie Morgan table. The number of samples (S) used is determined by population $(\mathrm{N})$, with a confidence level of $90 \%$, as shown in Table 3.1. the following:

Tabel 3.1. Jumlah Populasi dan Sam
\begin{tabular}{r|r|}
\hline $\begin{array}{c}\text { Jumlah } \\
\text { Populasi (N) }\end{array}$ & $\begin{array}{c}\text { Jumlah } \\
\text { Sampel (S) }\end{array}$ \\
\hline 100 & 73 \\
200 & 115 \\
300 & 143 \\
400 & 162 \\
500 & 176 \\
600 & 187 \\
$\mathbf{7 0 0}$ & $\underline{\mathbf{1 9 2}}$ \\
800 & 203 \\
900 & 209 \\
1000 & 214 \\
\hline \multicolumn{2}{|c|}{ Sumber: Setabasri 2012 }
\end{tabular}

Based on Table 3.1 with a value of $N=673$, a sample of $S=192$ respondents was obtained. Of the 192 respondents, there were 6 respondents who were invalid so they could not be included as research data, so the number of valid samples was only 186 respondents.

This research was conducted at Universitas Ciputra Surabaya. The data used for descriptive statistical analysis were distributed to respondents using a questionnaire. The questionnaire used refers to the Servqual method using five factors, namely Reliability, Responsiveness, Assurance, Empathy and Tangibles which are measured using a Likert scale with the following format:

1. Strongly Disagree

2. Do not agree 
3. Neutral

4. Agree

5. Strongly agree

\subsection{Research Result Test}

\subsubsection{Validity and Reliability Test}

According to Sugiyono (2011), in qualitative research, findings or data can be declared valid if there is no difference between what was reported by the researcher and what actually happened to the object being studied. According to Sugiyono (2011), qualitative research, a reality is multiple or multiple, dynamic or always changing, so that nothing is consistent, and repeats itself as before. The reliability test generally uses the Cronbach Alpha coefficient. The Cronbach Alpha test was performed for two reasons. First, because this technique is the most frequently used questionnaire reliability testing technique (Bell et al., 2015). Second, by performing the Cronbach Alpha test, inconsistent indicators will be detected. High reliability is indicated by the rxx value close to 1 . General agreement on reliability the general agreement on reliability is considered satisfactory if $>0.700$. Testing the reliability of the instrument using the Cronbach Alpha formula because this research is in the form of a questionnaire and a graded scale. Cronbach's Alpha formula is as follows:

$$
r_{11}=\left(\frac{n}{n-1}\right)\left(1-\frac{\sum \sigma_{t}^{2}}{\sigma_{t}^{2}}\right)
$$

Description:

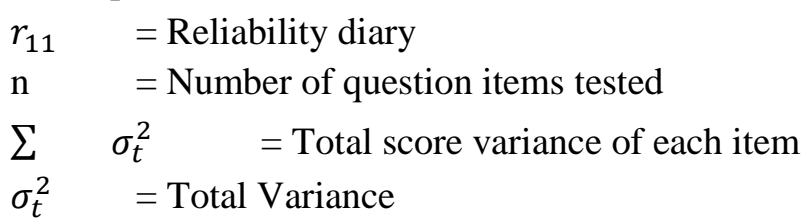

If the alpha value $>0.70$ it means sufficient reliability, while if the alpha $>0.80$ it suggests that all items are reliable and all tests consistently have strong reliability. If alpha $>0.90$ then the reliability is perfect. So if the alpha is between $0.70-0.90$ then the reliability is high or can be accepted by most instruments. If the alpha is $0.50-0.70$ then the reliability is moderate or not good. If alpha $<0.50$ then the reliability is low. If the alpha is low, it is possible that one or more items are not reliable.

\subsubsection{Descriptive Data Analysis}

The data from the questionnaires that have been collected will be processed using a descriptive statistical approach where the data will be processed according to its function. The results of the processing will then be presented in the form of numbers to make it easier to understand. Data processing will be carried out with the help of the SPSS Statistics application program, from the processed data information will be obtained about the level of satisfaction for each factor through the mean value and how big the spread is through the standard deviation value. Information from the processing results will be presented in the form of graphs and analysis for each factor. The steps taken are:

\section{Data Tabulation}

The first stage is data tabulation. In the data tabulation process, the existing data is compiled and displayed in the form of a table that has been separated based on a questionnaire with details in the form of questions on the questionnaire, along with how many respondents for each level of satisfaction there are. Through the data tabulation process, we can see the overall results of the questionnaires that have been distributed

2. Calculating Average Score

The second stage is the calculation of the average value. The calculation of this average value will be divided into four parts, namely:

a. Average per Question Item

Calculation of the average value per question item will help us to know specifically the level of satisfaction of each item. Although in the end the level of satisfaction is considered good, not all items measured are of good value, and vice versa. From this measurement, it will be described specifically, what items are of less value that need to be improved, and what items are of good value to be maintained. 
b. Average per Questionnaire

The average calculation per questionnaire was carried out to determine the level of satisfaction of each user. From the results of this calculation will describe a general description of the level of user satisfaction.

c. Average per Satisfaction Factor

The results of the calculation of the satisfaction factor will provide an overview of the level of satisfaction of each factor. Calculation of each satisfaction factor from each questionnaire so that its value is not dominated by the questionnaire with the most respondents.

d. Overall Average

The results of the overall average calculation will explain how high or low the level of student satisfaction is. This average value will be calculated from the average value of each factor from each questionnaire.

\subsubsection{Calculating Standard Deviation}

The standard deviation value will be calculated with the same division as the average calculation, namely the question item, questionnaire, satisfaction factor and overall. The results of the calculation of the standard deviation will describe how much the data spread from the existing average value.

\section{Result and Discussion}

\section{1. $\quad$ Research Approach}

Universitas Ciputra Surabaya (UC) is a private university in Surabaya, Indonesia. This university was founded on August 26, 2006. To be able to excel and meet the needs of the community in the field of education, Universitas Ciputra Surabaya always provides the best facilities and infrastructure to support learning activities which include: classrooms, library rooms, laboratory rooms, studio rooms, auditoriums, theaters, along with other public facilities. The management system for facilities and infrastructure at Universitas Ciputra Surabaya is carried out centrally under the Property Management (PM) department. The services in the PM department include: the process of procurement and maintenance of facilities, campus security, parking, cleanliness, and beauty of the campus environment, as well as assisting the implementation of student activities. Students are the main customers of Universitas Ciputra Surabaya, therefore it is very important to maintain and improve the quality of service to students. Responding to these conditions makes Universitas Ciputra Surabaya always maintain the quality of service and environmental comfort for students, where the comfort of the environment is supported by the quality of cleanliness, the function of existing infrastructure.

This research was conducted on Universitas Ciputra Surabaya students located in Surabaya, East Java. This research was conducted from February 2020 to September 2020. This study aims to obtain an overview and quality of Universitas Ciputra Surabaya Property Management services from the perspective of service users, namely students based on five dimensions of SERVQUAL quality, namely Tangible, Reliability, Responsiveness, Assurance, and Empathy.

\section{2. $\quad$ Research Results and Discussion}

\subsubsection{Validity test}

Correlation test was conducted between factors and Servqual statements which included Tangible, Reliability, Responsiveness, Assurance, and Empathy aspects to determine validity, with a total of 186 questionnaires and an alpha value $(5 \%)$ then the correlation test value between factors with a total value must exceed 0.148 so that the points are declared valid.

Tabel 4.1. Validity test

\begin{tabular}{|c|l|r|c|}
\hline \multicolumn{2}{|c|}{ TANGIBLES } & $\begin{array}{c}\text { Coefficient Correlation Test } \\
\text { Value to total }\end{array}$ & Description \\
\hline 1 & $\begin{array}{l}\text { In my opinion, the condition of the UC Building is well } \\
\text { maintained }\end{array}$ & 0.575 & Valid \\
\hline 2 & $\begin{array}{l}\text { Learning facilities that support teaching and learning } \\
\text { activities (tables, chairs, blackboards, etc.) are adequate }\end{array}$ & 0.461 & Valid \\
\hline 3 & $\begin{array}{l}\text { Learning facilities other than classrooms (eg } \\
\text { laboratories, studios, gathering rooms) that are relevant } \\
\text { to the scientific needs of students }\end{array}$ & 0.498 & Valid \\
\hline 4 & Cool lecture room & 0.391 & Valid \\
\hline
\end{tabular}




\begin{tabular}{|c|c|c|c|}
\hline 5 & Campus facilities in general have been kept clean & 0.530 & Valid \\
\hline 6 & The elevator condition is adequate & 0.491 & Valid \\
\hline 7 & The condition of the parking area is adequate & 0.413 & Valid \\
\hline \multicolumn{4}{|c|}{$\begin{array}{ll}\text { RELIABILITY } \\
\end{array}$} \\
\hline 13 & $\begin{array}{l}\text { PM staff informed me of the deadline for the completion } \\
\text { of the work complaint I submitted }\end{array}$ & 0.812 & Valid \\
\hline 14 & PM staff provide fast service to me & 0.838 & Valid \\
\hline 15 & PM staff are always willing to help me & 0.825 & Valid \\
\hline 16 & $\begin{array}{l}\text { PM staff always provide time to respond to my needs in } \\
\text { carrying out activities (bazaar, seminar, oweek) at UC }\end{array}$ & 0.779 & Valid \\
\hline \multicolumn{4}{|c|}{ ASSURANCE } \\
\hline 17 & I always get comfort in service from PM staff & 0.871 & Valid \\
\hline 18 & PM staff are polite in providing service & 0.787 & Valid \\
\hline 19 & $\begin{array}{l}\text { The information I receive from the PM staff is always } \\
\text { clear }\end{array}$ & 0.845 & Valid \\
\hline 20 & $\begin{array}{l}\text { The information provided by PM staff is in accordance } \\
\text { with the conditions in the field }\end{array}$ & 0.842 & Valid \\
\hline \multicolumn{4}{|c|}{$\begin{array}{ll}\text { EMPATHY } & \text { EMPATH }\end{array}$} \\
\hline 21 & $\begin{array}{l}\text { PM staff understand my difficulties regarding the } \\
\text { implementation of activities }\end{array}$ & 0.802 & Valid \\
\hline 22 & PM operating hours according to my needs & 0.762 & Valid \\
\hline 23 & PM staff put the interests of students first & 0.786 & Valid \\
\hline 24 & $\begin{array}{l}\text { PM staff are willing to help when I'm having trouble } \\
\text { implementing an event/activity }\end{array}$ & 0.847 & Valid \\
\hline
\end{tabular}

Source: Data processed, 2020

The data above shows the correlation coefficient test value for each valid factor, because it is worth more than 0.148.

\subsubsection{Reliability Test}

The reliability test was carried out to see the consistency of the answers in answering the questionnaire, using Cronbach's Alpha value by comparing the $r$ value of the results with the $r$ table value. The data is declared reliable if the coefficient value of Cronbach's Alpha is greater than 0.6 for each factor. Table 4.2. shows the reliability test for all factors of this study.

Table 4.2. Reliability Test

\begin{tabular}{|c|c|c|c|}
\hline \multicolumn{2}{|r|}{ TANGIBLES } & Coefficient Correlation & Description \\
\hline 1 & $\begin{array}{l}\text { In my opinion, the condition of the UC Building is well } \\
\text { maintained }\end{array}$ & 0.960 & Reliable \\
\hline 2 & $\begin{array}{l}\text { Learning facilities that support teaching and learning activities } \\
\text { (tables, chairs, blackboards, etc.) are adequate }\end{array}$ & 0.961 & Reliable \\
\hline 3 & $\begin{array}{l}\text { Learning facilities other than classrooms (eg laboratories, } \\
\text { studios, gathering rooms) that are relevant to the scientific } \\
\text { needs of students }\end{array}$ & 0.960 & Reliable \\
\hline 4 & Cool lecture room & 0.962 & Reliable \\
\hline 5 & Campus facilities in general have been kept clean & 0.960 & Reliable \\
\hline 6 & The elevator condition is adequate & 0.962 & Reliable \\
\hline 7 & The condition of the parking area is adequate & 0.964 & Reliable \\
\hline \multicolumn{4}{|c|}{ RELIABILITY } \\
\hline 8 & $\begin{array}{l}\text { UC PM staff helped my needs in preparing student activities } \\
\text { (bazaar, UKM, seminar) at UC location }\end{array}$ & 0.958 & Reliable \\
\hline 9 & $\begin{array}{l}\text { If I have a problem in carrying out an activity, the PM staff will } \\
\text { really help solve it }\end{array}$ & 0.958 & Reliable \\
\hline 10 & PM staff provide service right from the start & 0.957 & Reliable \\
\hline 11 & The service I receive is always on time, as promised. & 0.958 & Reliable \\
\hline 12 & The information I received from the PM staff is clear & 0.957 & Reliable \\
\hline \multicolumn{4}{|c|}{ RESPONSIVENESS } \\
\hline 13 & $\begin{array}{l}\text { PM staff informed me of the deadline for the completion of the } \\
\text { work complaint I submitted }\end{array}$ & 0.957 & Reliable \\
\hline 14 & PM staff provide fast service to me & 0.957 & Reliable \\
\hline 15 & PM staff are always willing to help me & 0.957 & Reliable \\
\hline 16 & $\begin{array}{l}\text { PM staff always provide time to respond to my needs in } \\
\text { carrying out activities (bazaar, seminar, oweek) at UC }\end{array}$ & 0.958 & Reliable \\
\hline \multicolumn{4}{|c|}{ ASSURANCE } \\
\hline
\end{tabular}




\begin{tabular}{|c|c|c|c|}
\hline 17 & I always get comfort in service from PM staff & 0.957 & Reliable \\
\hline 18 & PM staff are polite in providing service & 0.958 & Reliable \\
\hline 19 & The information I receive from the PM staff is always clear & 0.957 & Reliable \\
\hline 20 & $\begin{array}{l}\text { The information provided by PM staff is in accordance with the } \\
\text { conditions in the field }\end{array}$ & 0.957 & Reliable \\
\hline \multicolumn{4}{|c|}{\begin{tabular}{|c|} 
EMPATHY \\
\end{tabular}} \\
\hline 21 & $\begin{array}{l}\text { PM staff understand my difficulties regarding the } \\
\text { implementation of activities }\end{array}$ & 0.958 & Reliable \\
\hline 22 & PM operating hours according to my needs & 0.958 & Reliable \\
\hline 23 & PM staff put the interests of students first & 0.958 & Reliable \\
\hline 24 & $\begin{array}{l}\text { PM staff are willing to help when I'm having trouble } \\
\text { implementing an event/activity }\end{array}$ & 0.957 & Reliable \\
\hline
\end{tabular}

Source: Data processed, 2020

Table 4.2. above shows the test results for all factors are declared reliable, with Cronbach's Alpha value $>0.6$.

\subsubsection{Descriptive Data Analysis}

Of the 186 questionnaires, $66 \%$ of respondents were female while the remaining $34 \%$ of respondents were male. In this study, descriptive analysis was used to describe the respondents' perceptions of the factors studied. Descriptive analysis is done by looking at the average score of respondents' answers on each question item. discussion and discussion for each research variable:

1. Tangible

Table 4.3. Tangible Factors Descriptive Statistics

\begin{tabular}{|c|c|c|c|c|c|c|c|}
\hline $\begin{array}{c}\text { Factors / } \\
\text { Indicators } \\
\end{array}$ & Items & $\mathbf{N}$ & Minimum & Maximum & mean & $\begin{array}{c}\text { Category } \\
\text { Mean }\end{array}$ & $\begin{array}{c}\text { Std } \\
\text { Deviation } \\
\end{array}$ \\
\hline \multirow[t]{7}{*}{ Tangibles } & $\begin{array}{l}\text { In my opinion, the condition of the UC } \\
\text { Building is well maintained }\end{array}$ & 186 & 2 & 5 & 4.35 & Agree & 0.71 \\
\hline & $\begin{array}{l}\text { Learning facilities that support teaching } \\
\text { and learning activities (tables, chairs, } \\
\text { blackboards, etc.) are adequate }\end{array}$ & 186 & 1 & 5 & 4.18 & Agree & 0.84 \\
\hline & $\begin{array}{l}\text { Learning facilities other than classrooms } \\
\text { (eg laboratories, studios, gathering } \\
\text { rooms) that are relevant to the scientific } \\
\text { needs of students }\end{array}$ & 186 & 1 & 5 & 4.15 & Agree & 0.87 \\
\hline & Cool lecture room & 186 & 1 & 5 & 4.24 & Agree & 0.89 \\
\hline & $\begin{array}{l}\text { Campus facilities in general have been } \\
\text { kept clean }\end{array}$ & 186 & 2 & 5 & 4.44 & Agree & 0.71 \\
\hline & The elevator condition is adequate & 186 & 1 & 5 & 3.25 & Just agree & 1.33 \\
\hline & $\begin{array}{l}\text { The condition of the parking area is } \\
\text { adequate }\end{array}$ & 186 & 1 & 5 & 3.23 & Just agree & 1.38 \\
\hline \multicolumn{4}{|r|}{ Whole } & 3,98 & & Just Agree & $\mathbf{0 , 9 6}$ \\
\hline
\end{tabular}

Source: Data processed, 2020

Of the 7 statements, the highest mean value of 4.44 was in the statement that, "Campus facilities in general have been kept clean", respondents tended to agree, however, actually according to the research of Srinadi and Nilakusumawati (2008), although environmental cleanliness affects student satisfaction, but not the dominant factor. On the other hand, according to Purwandani et al. (2016), good management of facilities and infrastructure is expected to create a university that is clean, neat, beautiful, comfortable and in pleasant conditions as a learning environment, so it needs to be managed properly.

2. Reliability

Table 4.4. Reliability Factor Descriptive Statistics

\begin{tabular}{|c|c|c|c|c|c|c|c|}
\hline \multirow{2}{*}{ Factor } & \multicolumn{1}{|c|}{ Items } & N & Minimum & Maximum & mean & $\begin{array}{c}\text { Category } \\
\text { Mean }\end{array}$ & $\begin{array}{c}\text { Std } \\
\text { Deviation }\end{array}$ \\
\hline Reliability & $\begin{array}{l}\text { UC PM staff helped my needs in } \\
\text { preparing student activities (bazaar, } \\
\text { UKM, seminar) at UC location }\end{array}$ & 186 & 2 & 5 & 4.04 & Agree & 0.83 \\
\cline { 2 - 7 } & $\begin{array}{l}\text { If I have a problem in carrying out an } \\
\text { activity, the PM staff will really help } \\
\text { solve it }\end{array}$ & 186 & 1 & 5 & 3.88 & Just agree & 0.89 \\
\hline
\end{tabular}




\begin{tabular}{|l|l|c|c|c|c|c|c|}
\hline & $\begin{array}{l}\text { PM staff provide service right from } \\
\text { the start }\end{array}$ & 186 & 1 & 5 & 3.95 & Just agree & 0.82 \\
\cline { 2 - 7 } & $\begin{array}{l}\text { The service I receive is always on } \\
\text { time, as promised. }\end{array}$ & 186 & 2 & 5 & 3.95 & Just agree & 0.83 \\
\cline { 2 - 6 } & $\begin{array}{l}\text { The information I received from the } \\
\text { PM staff is clear }\end{array}$ & 186 & 5 & 4.06 & Agree & 0.83 \\
\hline
\end{tabular}

Source: Data processed 2020

Of the 5 statements, the highest mean value of 4.06 was in the statement "The information I received from the PM Staff was clear", with a standard deviation of 0.83 which received approval from the respondents. On the other hand, the lowest mean value is in the statement "If I have a problem in carrying out activities, the PM staff will really help solve it" which has a mean of 3.88 and a standard deviation of 0.889 which is only considered quite agreeable by respondents so that it is necessary to improve service quality.

3. Responsiveness

Table 4.5. Responsiveness Factor Descriptive Statistics

\begin{tabular}{|c|l|r|r|r|r|r|r|}
\hline Factor & \multicolumn{1}{|c|}{ Items } & N & Minimum & Maximum & mean & $\begin{array}{c}\text { Category } \\
\text { Mean }\end{array}$ & $\begin{array}{c}\text { Std } \\
\text { Deviation }\end{array}$ \\
\hline Responsiveness & $\begin{array}{l}\text { PM staff informed me of the deadline for } \\
\text { the completion of the work complaint I } \\
\text { submitted }\end{array}$ & 186 & 2 & 5 & 3.94 & Just agree & 0.82 \\
& PM staff provide fast service to me & 186 & 1 & 5 & 3.92 & Just agree & 0.88 \\
\hline & PM staff are always willing to help me & 186 & 1 & 5 & 4.02 & Agree & 0.84 \\
\hline & $\begin{array}{l}\text { PM staff always provide time to respond } \\
\text { to my needs in carrying out activities } \\
\text { (bazaar, seminar, oweek) at UC }\end{array}$ & 186 & 2 & 5 & 3.99 & Just agree & 0.83 \\
& & & Whole & $\mathbf{3 . 9 7}$ & $\begin{array}{c}\text { Just } \\
\text { agree }\end{array}$ & $\mathbf{0 . 8 5}$ \\
\hline
\end{tabular}

Source: Data processed, 2020

From the 4 statements, the highest mean value of 4.02 is in the statement, "PM staff are always willing to help me" with a standard deviation of 0.84 which has, obtained an agreeable answer from the respondents. The lowest mean value is in the statement, "PM staff provide excellent service quick to me" with a mean of 3.93 and a standard deviation of 0.88 . Where respondents tend to only rate quite agree, so that the service speed is concluded to be lacking and needs to be improved.

4. Assurance

Table 4.5. Assurance Factor Descriptive Statistics

\begin{tabular}{|c|l|r|r|r|r|r|r|}
\hline Factor & \multicolumn{1}{|c|}{ Items } & N & Minimum & Maximum & mean & $\begin{array}{c}\text { Category } \\
\text { Mean }\end{array}$ & $\begin{array}{c}\text { Std } \\
\text { Deviation }\end{array}$ \\
\hline Assurance & $\begin{array}{l}\text { I always get comfort in service from PM } \\
\text { staff }\end{array}$ & 186 & 2 & 5 & 3.98 & Agree & 0.879 \\
\hline & PM staff are polite in providing service & 186 & 1 & 5 & 4.10 & Agree & 0.852 \\
\hline & $\begin{array}{l}\text { The information I receive from the PM } \\
\text { staff is always clear }\end{array}$ & 186 & 1 & 5 & 4.03 & Agree & 0.828 \\
& $\begin{array}{l}\text { The information provided by PM staff is } \\
\text { in accordance with the conditions in the } \\
\text { field }\end{array}$ & 186 & 1 & 5 & 4.02 & Agree & 0.841 \\
\hline
\end{tabular}

The results of the Assurance questionnaire obtained the highest mean value in the statement, "PM staff are polite in providing services", with a mean of 4.10 and a standard deviation of 0.85 , which means that respondents agree with the courtesy of PM staff. The lowest mean value of 3.98 with a standard deviation of 0.879 is in the statement, "I always get comfort in service from PM staff" which is considered sufficient by students. This illustrates that respondents tend to not feel comfortable when receiving services from PM staff.

5. Empathy

Table 4.6. Empathy Factor Descriptive Statistics

\begin{tabular}{|c|c|c|c|c|c|c|c|}
\hline Factor & Items & $\mathbf{N}$ & Minimum & Maximum & mean & $\begin{array}{l}\text { Category } \\
\text { Mean }\end{array}$ & $\begin{array}{c}\text { Std } \\
\text { Deviation }\end{array}$ \\
\hline Empathy & $\begin{array}{l}\text { PM staff understand my difficulties } \\
\text { regarding the implementation of activities }\end{array}$ & 186 & 1 & 5 & 3.94 & $\begin{array}{c}\text { Just } \\
\text { Agree }\end{array}$ & 0.85 \\
\hline
\end{tabular}




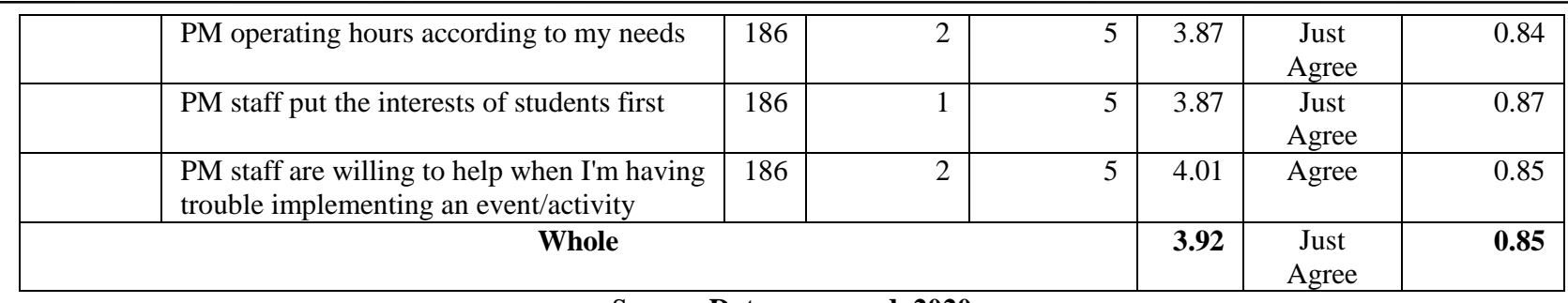

Source: Data processed, 2020

Of the 4 statements, the highest mean value of 4.01 with a standard deviation of 0.85 is in the statement, "PM staff are willing to help when I am having difficulties in carrying out an event or activity", from the results of the questionnaire, it can be seen that the respondents agreed with the statement. Meanwhile, the lowest mean value of 3.87 was in the statements that, "PM operational times are in accordance with my needs" and "PM staff put the interests of students first". Both of these statements are considered less by the respondents.

\section{Conclusions and Practical Implication}

\subsection{Conclusion}

From the results of the analysis of the quality of PM services at Universitas Ciputra Surabaya, the following conclusions were drawn: The average value of the overall level of respondents' satisfaction with PM service quality is 3.98, which means that the average respondent is still not satisfied with the quality of services provided by PM. Based on the PM service quality analysis in terms of five dimensions of service quality, respondents answered that the best quality was on Assurance and the lowest on Empathy. Assurance has an average value of 4.03 where the respondents considered satisfied, while Empathy has the lowest average level of satisfaction, which is 3.92 and should be the main concern for improving the quality of PM services. The results of this study become a recommendation for the PM department to improve the quality of services for students.

Suggestions that can be conveyed from the results of the service satisfaction analysis of PM Universitas Ciputra Surabaya include: From the results of the study it can be seen that PM at Universitas Ciputra Surabaya needs to improve service quality, to increase student satisfaction, through various activities that have been proposed in managerial implications. Provide knowledge about PM services on a regular basis to the entire PM team. Inform all students about PM services. Measurement of student satisfaction in enjoying PM services needs to be done regularly. For further research, it is necessary to conduct research that examines whether or not there is an influence between service quality on student satisfaction which has an impact on whether or not they intend to share their experiences while studying at UC to others. This needs to be done considering that this research still focuses on descriptive analysis related to student satisfaction in enjoying the services provided by UC through the PM department.

\subsection{Practical Implication}

Table 5.1. Managerial Implications

\begin{tabular}{|c|c|c|c|}
\hline No & $\begin{array}{c}\text { Service quality } \\
\text { indicators }\end{array}$ & Before Research & After research \\
\hline 1 & Tangible & $\begin{array}{l}\text { UC parking capacity is limited, only in } \\
\text { west parking area, hill parking and } \\
\text { building parking }\end{array}$ & $\begin{array}{l}\text { Collaborating with Tower Apartments Denver for } \\
\text { additional vehicle parking areas }\end{array}$ \\
\hline \multirow[t]{3}{*}{2} & \multirow[t]{3}{*}{ Reliability } & \multirow[t]{3}{*}{$\begin{array}{l}\text { There is no work standard in service to } \\
\text { students }\end{array}$} & $\begin{array}{l}\text { Determination of work standards by making } \\
\text { Service SOPs in the PM Department }\end{array}$ \\
\hline & & & $\begin{array}{l}\text { Comparative study to other campuses to improve } \\
\text { service quality }\end{array}$ \\
\hline & & & $\begin{array}{l}\text { Regular monitoring of student activities at UC, } \\
\text { together with BMA and majors }\end{array}$ \\
\hline \multirow[t]{2}{*}{3} & \multirow[t]{2}{*}{ Responsiveness } & \multirow[t]{2}{*}{$\begin{array}{l}\text { There is no standard speed in responding } \\
\text { to complaints and training related to } \\
\text { communication and body posture }\end{array}$} & $\begin{array}{l}\text { Increase the speed of service by determining the } \\
\text { time limit in answering complaints, namely } \mathrm{H}+2 \\
\text { which is stated in the SOP so that it becomes a } \\
\text { guide in serving students }\end{array}$ \\
\hline & & & $\begin{array}{l}\text { Training on how to handle customers in a } \\
\text { professional manner, and training related to } \\
\text { communication skills and posture }\end{array}$ \\
\hline 4 & Assurance & $\begin{array}{l}\text { There has been no briefing on PM } \\
\text { services on a regular basis to all PM staff }\end{array}$ & $\begin{array}{l}\text { Provision of knowledge about existing services in } \\
\text { PM, by making } Q n A \text {. documents }\end{array}$ \\
\hline
\end{tabular}




\begin{tabular}{|l|l|l|l|}
\cline { 3 - 4 } & Empathy & $\begin{array}{l}\text { Regularly update PM team members } \\
\text { operating hours }\end{array}$ \\
\hline & & $\begin{array}{l}\text { Assign one or more PM staff to be on standby on } \\
\text { campus when there are student activities }\end{array}$ \\
\cline { 2 - 4 } & $\begin{array}{l}\text { Ask the committee to fill out (must appear in the } \\
\text { discussion above) the PM service questionnaire }\end{array}$ \\
\hline
\end{tabular}

\section{References}

Alifuddin, B. (2012). Pemasaran stratejik jasa pendidikan. Bandung: Alfabeta.

Bell, E., Bryman, A., \& Harley, B. (2015). Business research methods. Oxford university press.

Gold, E. (2001). Customer service: A key unifying force for today's campus. In Retrieved on October (Vol. 13). Netresults, National Association of Student Personnel Administrators.

Hanssen, T.-E. S., \& Solvoll, G. (2015). The importance of university facilities for student satisfaction at a Norwegian University. Facilities, 33(13/14), 744-759. https://doi.org/10.1108/F-11-2014-0081

Hasan, H. F. A., Ilias, A., Rahman, R. A., \& Razak, M. Z. A. (2009). Service quality and student satisfaction: A case study at private higher education institutions. International Business Research, 1(3), 163-175. https://doi.org/10.5539/ibr.v1n3p163

Irawan, H. (2003). Principles of customer satisfaction. Jakarta: PT Elex Media.

Kärnä, S., \& Julin, P. (2015). A framework for measuring student and staff satisfaction with university campus facilities. Quality Assurance in Education, 23(1), 47-66. https://doi.org/10.1108/QAE-10-2013-0041

McLaughlin, P., \& Faulkner, J. (2012). Flexible spaces ... what students expect from university facilities. Journal of Facilities Management, 10(2), 140-149. https://doi.org/10.1108/14725961211218776

Parasuraman, A., Zeithaml, V. A., \& Berry, L. L. (1988). SERVQUAL: A multiple-item scale for measuring consumer perceptions of service quality. Journal of Retailing, 64(1), 12-40.

Purwandani, D., Sutarsih, C., \& Sururi. (2016). Pengaruh mutu layanan sarana dan prasarana terhadap kepuasan mahasiswa di fakultas pendidikan teknologi dan kejuruan Universitas Pendidikan Indonesia. Jurnal ADPEND Tata Kelola Pendidikan, 1(1), 80-90.

Sopiatin, P. (2010). Manajemen belajar berbasis kepuasan siswa. Bogor: Ghalia Indonesia.

Srinadi, I. G. A. M., \& Nilakusmawati, D. P. E. (2008). Faktor-faktor penentu kepuasan mahasiswa terhadap pelayanan fakultas sebagai lembaga pendidikan (Studi kasus di FMIPA, Universitas Udayana). Jurnal Cakrawala Pendidikan, 27(3), 217-231. https://doi.org/10.21831/cp.v3i3.32210.21831/cp.v3i3.322

Sugiyono. (2011). Metodologi penelitian kuantitatif kualitatif dan $R \backslash \& D$. Bandung: Alfabeta.

Sugiyono. (2015). Pendekatan kuantitatif, kualitatif, and R\&D. Bandung: Alfabeta.

Tjiptono, F., \& Chandra, G. (2011). Service, quality, \& satisfaction (3rd ed.). Yogyakarta: Andi.

Tjiptono, Fandy. (2005). Pemasaran Jasa, edisi pertama. Malang: Bayu Media Publishing.

Weerasinghe, I. M. S., \& Fernando, R. L. S. (2018). University facilities and student satisfaction in Sri Lanka. International Journal of Educational Management, 32(5), 866-880. https://doi.org/10.1108/IJEM-07-20170174

Wijatno, S. (2009). Pengelolaan perguruan tinggi secara efisien, efektif, dan ekonomis untuk meningkatkan mutu penyelenggaraan pendidikan dan mutu lulusan. Penerbit Salemba Empat. 